Research Paper:

\title{
Determinants of Stunting Incidence in Children Under Five Years of Age at the Rumbia Health Center, Indonesia
}

Sudrayani Usman ${ }^{1}$, Wa Ode Salma ${ }^{2 *}$, Asriati Asriati ${ }^{3}$ (iD

1. Department of Health, College of Public Health, Haluoleo University, Kendari, Indonesia

2. Departement of Nutrition, College of Public Health, Haluoleo University, Kendari, Indonesia.

3. Departement of Medicine, Faculty of Medicine, Haluoleo University, Kendari, Indonesia.

\begin{tabular}{|c|c|}
\hline $\begin{array}{l}\text { Use your device to scan } \\
\text { and read the article online }\end{array}$ & dteat on: Usman, S., Salma, W. O., Asriati, A. 2021. Determinants of Stunting Incidence in Children Under Five Years of Age \\
\hline arita & $\begin{array}{l}\text { at the Rumbia Health Center, Indonesia. Journal of Client-Centered Nursing Care, 7(4), pp. 295-302. https://doi.org/10.32598/ } \\
\text { JCCNC.7.4.387.1 }\end{array}$ \\
\hline 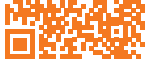 & dol'https://doi.org/10.32598/JCCNC.7.4.387.1 \\
\hline
\end{tabular}

(c) (1) (8)

Article info:

Received: 21 Aug 2021

Accepted: 02 Oct 2021

Published: 01 Nov 202

Keywords:

Children, Risk factors, Growth disorders

\begin{abstract}
A B S T RA C T
Background: Stunting is linear growth retardation and a major public health problem among children worldwide. This study was done to investigate the determinants of stunting in children under five years at the Rumbia Health Center, Indonesia.

Methods: This case-control study was done on 82 (41 cases and 41 controls) subjects matched by age and sex, taken by purposive sampling involving infants and children aged 6-59 months in Rumbia District, Bombana Regency, Indonesia, consisting of 5 Village. Data were collected using medical records and a researcher-made questionnaire and analyzed by odds ratios and logistic regression using SPSS 16. The significance level was set at 0.05 .

Results: The results based on multivariate analysis showed that the incidence of stunting was influenced by a number of factors, including a history of exclusive breastfeeding $(\mathrm{OR}=0.352)$, birth weight $(\mathrm{OR}=5.106)$, family income $(\mathrm{OR}=0.703)$, and mother's education level $(\mathrm{OR}=0.175)$. However, the mother's education level was significantly related to the incidence of stunting in this analysis model $(\mathrm{P}=0.003)$.

Conclusion: Indonesian mothers should be more active in accessing information about stunting and how to prevent it. Community health nurses and other members of the health care team are recommended to intensify the provision of stunting education and information to the community, especially to at-risk families. Also, special attention must be paid to women's access to higher education.
\end{abstract}

\section{*Corresponding Author:}

Wa Ode Salma, PhD.

Address: Departement of Nutrition, College of Public Health, Haluoleo University, Kendari, Indonesia.

Tel: +62 (813) 42176979

E-mail: salmawaode849@gmail.com 


\section{Highlights}

- Chronic malnutrition is recognized as the best indicator of the quality of human capital of a country.

- Many children in underdeveloped countries suffer from stunting or low height for age.

- Stunting leads to wide-ranging adverse outcomes, including short-term outcomes, such as morbidity and mortality in infants/toddlers, medium-term outcomes, such as reduced mental and cognitive abilities, and long-term outcomes, including its impact on human resource quality and degenerative diseases in adulthood.

- The findings of this study showed that lower levels of maternal education greatly affect the incidence of stunting in children.

\section{Plain Language Summary}

Stunting in children is a form of growth disorder caused by chronic malnutrition, especially in the first 1000 days of life. Stunting indicates a public health problem because it is associated with an increased risk of morbidity and mortality, decreased motor and mental function development, and reduced physical capacity. Many factors influence the incidence of stunting, including exclusive breastfeeding for less than 6 months of age, low birth weight, low family income, and low maternal education level. The findings of this study determined mothers' education as the predictor of the incidence of stunting in children.

\section{Introduction}

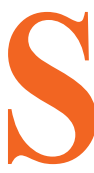

tunting or low height for age is a linear growth disorder or stunted growth that is considered a major public health problem among children worldwide. Around 151 million $(22 \%)$ children under five years of age in 2017 had stunting (Titaley et al.

2019). Worldwide, 5.6 million children die before the age of five each year, with $80 \%$ of these deaths occurring in Sub-Saharan Africa and Asia. Nearly half of these deaths occur in malnourished children and strong epidemiological evidence suggests that this is due to susceptibility to life-threatening infections among malnourished children (Walson \& Berkley 2018). The incidence of stunting is associated with low birth weight, which indicates a lack of proper nutrition in the long run, especially micronutrients associated with infectious diseases. Therefore, stunting and its effects could have a negative impact on the quality of life of children and the formation of human resources in the future (Alifariki 2020; Rangki et al. 2020).

In Africa, the burden of stunting is heavy with a prevalence of $36 \%$, and is generally around $40 \%$ in rural areas and $25 \%$ in urban areas (Abeway et al. 2018). Most of the deaths from stunting are associated with the level of knowledge of mothers and poverty factors that occur in the first five years of life. Therefore, strengthening the health system to improve child health through prioritizing mothers and children by overcoming poverty and increasing access to food is needed as a strategy to improve sustainable child nutrition (Habimana \& Biracyaza 2019).

Stunting is a nutritional problem in children with length/age or height/age $(\mathrm{PB} / \mathrm{U}$ or $\mathrm{TB} / \mathrm{U})$ more than two standard deviations below the World Health Organization (WHO) Child Growth Standards median (Kemenkes 2018b). The WHO in 2018 reported that the prevalence of stunting in children under five years of age is about $21.9 \%$ (Headey \& Palloni 2020). Indonesia is the third country with the highest prevalence of stunting in Southeast Asia. The prevalence of stunting in Indonesia was recorded at $27.5 \%$ in 2016 , which increased to $29.6 \%$ in 2017, and reached $30.8 \%$ in 2018 (Kemenkes 2018a).

Based on the nutritional status of $\mathrm{PB} / \mathrm{U}$ or $\mathrm{TB} / \mathrm{U}$ in 2018, the prevalence of stunting in Southeast Sulawesi Province was $2.67 \%$, with the category of very short children and the category of short children being at $5.25 \%$. Based on the nutritional status of the TB/U index, this figure increased in 2019 and included an increase in the very short children category by $3.25 \%$ and in the short children category by $13.67 \%$. Referring to the data from the Bombana District Health Office of Indonesia in 2019, the number of very short and short children at the Rumbia Health Center was 67 (36.02\%). It is known that stunting in children as chronic malnutrition is caused by many factors, such as socioeconomic con- 
ditions, maternal nutrition during pregnancy, infectious diseases during infancy, and lack of nutritional intake in infants, and these children will experience difficulties in achieving optimal physical and cognitive development in the future (Kemenkes 2019).

Due to the lack of efforts to provide nutrition for children during the COVID-19 epidemic, there is concern that the rate of stunting in Indonesian children will increase (Lawaceng \& Rahayu 2019). Age-inappropriate growth and development can also signify that a child's immune system has decreased, making them more susceptible to infection, including pathogens, such as the coronavirus (Akseer et al. 2020). Repeated infections disrupt the gastrointestinal tract of the child and cause malabsorption of nutrients; hence, there is a risk of suffering from malnutrition and if not detected, will eventually interfere with growth hormone in the long run and lead to stunting.

Various studies have been carried out on the determinants of stunting in children; some of them assessed stunting associated with poor environmental quality (Sulastri 2012; Vilcins, Sly \& Jagals 2018; Budge et al. 2019; Marni 2020), parents' demographic factors, especially mothers (Hall et al. 2018; Buisman et al. 2019), family socioeconomic factors (Zottarelli, Sunil \& Rajaram 2007; Mantovani et al. 2016; Binagwaho et al. 2020), and maternal nutritional intake during pregnancy (Van Stuijvenberg et al. 015; Dewey 2016). According to the foreword, this study was carried out with the aim of investigating the determinants of stunting in children under five years of age at the Rumbia Health Center, Indonesia.

\section{Materials and Methods}

The current study was conducted in the Work Area of the Rumbia Health Center, Rumbia District, Bombana Regency, and Southeast Sulawesi Province during the COVID-19 pandemic, involving four kelurahan (sub-district) and one village. A case-control design was applied by involving 82 children aged 6-59 months (41 cases and 41 controls) matched by age and sex. Children with congenital growth disorders and Down syndrome who have been medically identified by doctors/pediatricians were not included in the study. Stunting was determined based on the nutritional status of the children i.e., body length index according to age $(\mathrm{PB} / \mathrm{U}$ or $\mathrm{TB} / \mathrm{U})$ within the threshold (anthropometric standards for assessment of child nutritional status) referring to WHO standard reported in 2005 (Kemenkes 2019). Furthermore, children under five years of age were grouped as normal (TB/U $-2 \mathrm{SD}$ to $+3 \mathrm{SD})$ and stunting $(\mathrm{TB} / \mathrm{U}<-2 \mathrm{SD})$. Other vari- ables were the history of exclusive breastfeeding, family income, birth weight, and mother's education, which were collected using a questionnaire. The questionnaire was made by the researcher based on the questionnaire that had been used in previous studies and its validity was confirmed, and then, it was given to the mothers to be answered. The history of exclusive breastfeeding was classified by yes-no questions; yes, if the baby has been exclusively breastfed until the age of 6 months, and no, if the baby is breastfed before the age of 6 months.

Birth weight was divided into two categories, namely Low Birth Weight (LBW) if the baby's weight is $<2500$ $\mathrm{g}$ and normal birth weight if the baby's weight is $\geq 2500$ g. The family income was categorized as "low" if it was less than the provincial minimum wage standard, and "sufficient" if it was more or equal to the provincial minimum wage standard. The parents' education level was classified into low education (no completed primary school, elementary, junior high school, and senior high school) and higher education (baccalaureate, associate degree, and post-graduate). Data analysis was done using SPSS software version 16.0 and the Odds Ratio (OR) and multivariate logistic regression to find the determinants of stunting in children under five years of age. The significance level was set at 0.05 .

\section{Results}

The demographic characteristics of children and their parents are presented in Table 1. Table 2 represents the risk factor analysis on the frequency of stunting in the case and control groups. According to Table 3, the model showed that of the four independent variables analyzed, there was at least one variable related to the incidence of stunting. The variable that was significantly related to the incidence of stunting in this analysis model was the mother's education level $(\mathrm{P}=0.003)$. This model also explained that the analyzed independent variables contributed $34.5 \%$ to the incidence of stunting and $65.5 \%$ of stunting events were influenced by other factors not studied. In this analysis, it can also be concluded that the B value of the education level was 1.743 , which means that mothers who had low levels of education can increase the chances of having stunted children by 1.743 times.

\section{Discussion}

The results showed a significant relationship between birth weight and the incidence of stunting. LBW reflects public health problems, including long-term maternal malnutrition, poor health, hard work, and poor health care during pregnancy. $\mathrm{LBW}$ is an important predictor of the 
Table 1. Demographic characteristics of the children and their parents

\begin{tabular}{|c|c|c|}
\hline \multicolumn{2}{|c|}{ Variable } & \multirow{2}{*}{\begin{tabular}{|c|} 
No. (\%) \\
$34.6 \pm 2.35$
\end{tabular}} \\
\hline \multirow{3}{*}{ Age group } & Mean $\pm S D$ & \\
\hline & 6-11 months & $16(19.5)$ \\
\hline & $12-59$ months & $66(80.5)$ \\
\hline \multirow{2}{*}{ Gender } & Female & $47(57.3)$ \\
\hline & Male & $35(42.7)$ \\
\hline \multirow{2}{*}{ Family members } & $\leq 4$ people & $28(34.1)$ \\
\hline & $>4$ people & $54(65.9)$ \\
\hline \multirow{7}{*}{ Mother's education level } & Not Completed in primary school & $1(1.2)$ \\
\hline & Elementary & $8(9.8)$ \\
\hline & Junior high school & $24(29.3)$ \\
\hline & Senior high school & $30(36.6)$ \\
\hline & Associate degree & $8(9.8)$ \\
\hline & Baccalaureate & $10(12.2)$ \\
\hline & Post-graduate & $1(1.2)$ \\
\hline \multirow{7}{*}{ Father's education level } & \multirow{2}{*}{ Not Completed in primary school } & $2(2.4)$ \\
\hline & & $6(7.3)$ \\
\hline & Elementary & $14(17.1)$ \\
\hline & Junior nign school & $39(47.6)$ \\
\hline & Senior high school & $3(3.7)$ \\
\hline & Associate degree Baccalaureate & $17(20.7)$ \\
\hline & Post-graduate & $1(1.2)$ \\
\hline \multirow{4}{*}{ Mother's occupation } & Housewife & $64(78.0)$ \\
\hline & Civil servant/Police/Army & $8(9.8)$ \\
\hline & Private & $4(4.9)$ \\
\hline & Part-time worker/honorary & $6(7.3)$ \\
\hline \multirow{6}{*}{ Father's occupation } & Civil servant/Police/Army & $17(20.7)$ \\
\hline & Private & $18(22.0)$ \\
\hline & Entrepreneur & $26(31.7)$ \\
\hline & Farmer/Fisherman & $15(18.3)$ \\
\hline & Driver & $1(1.2)$ \\
\hline & Part-time worker/honorary & $5(6.1)$ \\
\hline
\end{tabular}

health and survival of newborns and is associated with a high risk of stunting in children (Sutan et al. 2014). It was found in a study that as many as $27(42.2 \%)$ of children had a history of LBW and 32(100\%) experienced stunting (Murti, Suryati \& Oktavianto 2020). Our result is also in line with a research in Lampung, which also stated that there was a relationship between birth weight and the incidence of stunting in children aged 6-59 months, and children with LBW had a 2.82 times risk of stunting (Alfarisi, Nurmalasari \& Nabilla 2019). This result is also congruent with research in Brazil that children with a birth weight of $<2,500 \mathrm{~g}$ showed a 3.53 times greater risk of stunting than those with a birth weight of $2500 \mathrm{~g}$ (de Menezes et al.
2011). The children of low-income families were mostly stunted and the relationship between the two variables was significant $(\mathrm{P}=0.01)$. Parents with adequate income will have the ability to provide all the primary and secondary needs of the child. Families with good economic status also have access to better health services. Children in families with low economic status tend to consume less food in quantity, quality, and variety. The high economic status allows a person to choose and buy nutritious and varied food (Aksol 2021). Previous evidence has also found a significant relationship between family income and the incidence of stunting (Harikatang et al. 2020). Family income is the root of nutritional problems, 
Table 2. Results of risk factor analysis on the frequency of stunting in cases and controls

\begin{tabular}{|c|c|c|c|c|}
\hline \multirow{2}{*}{\multicolumn{2}{|c|}{ Variable }} & \multicolumn{2}{|c|}{ No. (\%) } & \multirow{3}{*}{$\begin{array}{c}\text { Value } \\
\text { OR (LL-UL) } \\
1.8^{\mathrm{a}}\end{array}$} \\
\hline & & \multirow{2}{*}{$\begin{array}{c}\text { Stunting }(\mathbf{n}=\mathbf{4 1}) \\
19(46.3)\end{array}$} & \multirow{2}{*}{$\begin{array}{c}\text { Normal }(n=41) \\
25(61)\end{array}$} & \\
\hline History of exclusive breast & Exclusive & & & \\
\hline feeding & Non-exclusive & $22(53.7)$ & $16(39)$ & $(0.7-4.3)$ \\
\hline \multirow{2}{*}{ Birth weight } & Low Birth Weight (LBW) & $32(78.1)$ & 40(97.6) & $11.2^{\mathrm{b}}$ \\
\hline & Normal birth weight & $9(22)$ & $1(2.4)$ & $(1.3-93.5)$ \\
\hline \multirow{2}{*}{ Family income } & Low & $30(73.2)$ & 18(43.9) & $0.3^{b}$ \\
\hline & Sufficient & $11(26.8)$ & $23(56.1)$ & $(0.1-0.7)$ \\
\hline \multirow{2}{*}{ Mothers' Education level } & Low & $25(61)$ & $8(19.5)$ & $0.2^{\mathrm{c}}$ \\
\hline & High & $16(39)$ & $33(80.5)$ & $(0.1-0.4)$ \\
\hline
\end{tabular}

${ }^{\mathrm{a} P}>0.05,{ }^{\mathrm{b}} \mathrm{P}=0.01, \mathrm{c}<<0.0001$.

Table 3. Multivariate analysis of the risk factors for stunting

\begin{tabular}{ccccccc}
\hline Variable & B & S.E. & Wald & df & Sig. & Exp (B) \\
\hline History of exclusive breastfeeding & -544 & 0.251 & 1.091 & 1 & 0.332 & 0.352 \\
\hline Birth weight & 1.630 & 1.156 & 1.988 & 1 & 0.159 & 5.106 \\
\hline Family income & -0.353 & 0.568 & 0.386 & 1 & 0.534 & 0.703 \\
Mother's education level & -1.743 & 0.591 & 8.691 & 1 & 0.003 & 0.175 \\
\hline Constant & 3.689 & 2.114 & 3.044 & 1 & 0.081 & 40.008 \\
\hline R-square & & & & 0.345 & & \\
\hline
\end{tabular}

Client- Centered Nursing Care

including stunting in children (Ernawati et al. 2018). Income is an important factor in determining household expenditures, including family food consumption patterns. Good income will allow the family to consume nutritious food and access educational services useful for improving nutrition (Wu, et al. 2015).

Linear growth retardation is estimated to affect $34 \%$ of children younger than five years of age in lower-middleincome countries (Walker et al. 2007). Supported by the results of research conducted in Ethiopia and Madagascar, it is stated that socio-economic factors associated with low income and poverty are associated with stunting. Low family income increases the chances of stunting compared to affluent families by 3.1 times (Ernawati et al. 2018). There was a significant relationship between the mother's education and children's stunting. It was also shown that mothers who have low levels of education can increase the chances of having stunted children by 1.743 times.

Education level affects health indicators, one of which is nutritional status. Individuals who have a high level of education are likely to have greater knowledge about healthy lifestyles, such as consuming nutritious diets to have better health status. The level of education is related to income, where the level of income tends to increase as the level of education increases. The level of education also affects the level of good knowledge in choosing appropriate food wisely and handling health problems properly (Huang 2015).

The mother's education level is an important factor in supporting the health status of family members, including children. Mothers with higher education tend to easily accept new knowledge or information, including knowledge about processing and selecting good types of food for the family (Ni'mah \& Muniroh 2015). A study by Hizni in Cirebon City found a significant relationship between the level of maternal education and the incidence of stunting, in which mothers with low education had a 2.22 times greater risk of having stunted children than mothers with higher education (Rahayu \& Khairiyati 2014). Another study also found that a low level of education in fathers $(\mathrm{P}=0.017)$ and mothers $(\mathrm{P}<0.001)$ is a risk factor for stunting (Titaley et al. 2019). 


\section{Conclusion}

Birth weight, family income, and mother's education level are factors related to the incidence of stunting of children at the Rumbia Health Center, while the determinant of the incidence of stunting was the mothers' education level. Given that maternal education has a decisive role in the incidence and prevalence of stunting, Indonesian mothers, especially mothers living in the study area and similar areas in Indonesia, are advised to acquire the needed information about stunting and how to prevent it through the media. Community health nurses and other members of health teams working in these areas also need to be more active in educating and informing mothers, especially at-risk families about stunting. Also, special attention must be paid to women's access to higher education. This study was conducted in a small area, with unique features, and on a small sample; therefore, the findings should be used with caution.

\section{Ethical Considerations}

\section{Compliance with ethical guidelines}

This study was approved by the Haluoleo University Health Research Ethics Commission (80/KEPK-IAKMI/ $\mathrm{VI} / 2021$ ). The purpose of the study and the procedure for conducting the research were explained to the mothers as prospective respondents. After that, the mothers signed a letter of consent to become a respondent.

\section{Funding}

This research did not receive any grant from funding agencies in the public, commercial, or non-profit sectors.

\section{Authors' contributions}

All authors equally contributed to preparing this article.

\section{Conflict of interest}

The authors declared no conflict of interests.

\section{Acknowledgments}

The research team would like to thank the rector of Haluoleo University, Kendari, Indonesia, who has contributed during this research process and to Rumbia Health Center for providing the research team with the opportunity to conduct research.

\section{References}

Abeway, S., et al. 2018. Stunting and its determinants among children aged 6-59 months in northern Ethiopia: A crosssectional study. Journal of Nutrition and Metabolism, 2018, p. 1078480. [DOI:10.1155/2018/1078480] [PMID] [PMCID]

Akseer, N., et al. 2020. COVID-19 pandemic and mitigation strategies: Implications for maternal and child health and nutrition. The American Journal of Clinical Nutrition, 112(2), pp. 251-6. [DOI:10.1093/ajcn/nqaa171] [PMID] [PMCID]

Aksol, M. I., 2021. Pengaruh ekonomi faktor ekonomi terhadap gizi balita. [DOI:10.31219/osf.io/f87be]

Alfarisi, R., Nurmalasari, Y. \& Nabilla, S., 2019. Nutritional status of pregnant women can cause stunting in toddlers. Jurnal Kebidanan Malahayati, 5(3), pp. 271-8. [DOI:10.33024/jkm v5i3.1404]

Alifariki, L. O., et al. 2020. The proxy determinant of complementary feeding of the breastfed child delivery in less than 6 months old infant in the fishing community of Buton tribe. Enfermeria Clinica, 30(Supplement 4), pp. 544-7. [DOI:10.1016/j. enfcli.2019.10.135]

Alifariki, L. O., Kep, S. \& Kes, M., 2020. [Child nutrition and stunting (Indonesian)]. Yogyakarta: Penerbit LeutikaPrio. https://www.google.com/books/edition/Gizi_Anak_dan_ Stunting/e9kZEAAAQBAJ?hl=en\&gbpv=1\&dq

Binagwaho, A., et al. 2020. Trends in burden and risk factors associated with childhood stunting in Rwanda from 2000 to 2015: Policy and program implications. BMC Public Health, 20(1), pp. 1-9. [DOI:10.1186/s12889-020-8164-4] [PMID] [PMCID]

Budge, S., et al. 2019. Environmental enteric dysfunction and child stunting. Nutrition Reviews, 77(4), pp. 240-53. [DOI:10.1093/nutrit/nuy068] [PMID] [PMCID]

Buisman, L. R., et al. 2019. What explains the fall in child stunting in Sub-Saharan Africa? SSM - Population Health, 8, p. 100384. [DOI:10.1016/j.ssmph.2019.100384] [PMID] [PMCID]

Dewey, K. G., 2016. Reducing stunting by improving maternal, infant and young child nutrition in regions such as South Asia: Evidence, challenges and opportunities. Maternal $\mathcal{E}$ Child Nutrition, 12(Suppl 1), pp. 27-38. [DOI:10.1111/mcn.12282] [PMID] [PMCID]

Ernawati, D., et al. 2018. The relationship of socio-economic and genetic factors with toddler stunting at Kenjeran public health center Surabaya. Indian Journal of Public Health Research E Development, 9(11), pp. 1792-6. [DOI:10.5958/09765506.2018.01705.9]

Habimana, S. \& Biracyaza, E., 2019. Risk factors of stunting among children under 5 years of age in the eastern and western provinces of Rwanda: Analysis of Rwanda demographic and health survey 2014/2015. Pediatric Health, Medicine and Therapeutics, 10, p. 115-30. [DOI:10.2147/PHMT.S222198] [PMID] [PMCID]

Hall, C., et al. 2018. Maternal knowledge of stunting in rural Indonesia. International Journal of Child Health and Nutrition, 7(4), pp. 139-45. [DOI:10.6000/1929-4247.2018.07.04.2]

Harikatang, M. R., et al. 2020. [The relationship of mother's knowledge and attitude with stunting toddler incidents in one Kelurahan in Tangerang (Indonesian)]. Jurnal Mutiara Ners, 3(2), pp. 76-88. http:/ /e-journal.sari-mutiara.ac.id/index.php/ NERS/article/view/1178 
Headey, D. D. \& Palloni, G., 2020. Stunting and wasting among Indian preschoolers have moderate but significant associations with the vegetarian status of their mothers. The Journal of $\mathrm{Nu}$ trition, 150(6), pp. 1579-89. [DOI:10.1093/jn/nxaa042] [PMID] [PMCID]

Huang, W., 2015. Understanding the effects of education on health: Evidence from China [Internet]. IZA Discussion Paper. https:/ ftp.iza.org/dp9225.pdf

Kemenkes, R. I., 2018a. [Main results of RISKESDAS 2018, Jakarta: Ministry of health agency for health research and development [Internet] (Indonesian)]. https://persi.or.id/hasil-utamariskesdas-2018-kementerian-kesehatan-badan-penelitian-danpengembangan-kesehatan/

Kemenkes, R. I., 2018b. [Action plan for activities of the directorate of community nutrition for 2015-2019 [Internet] (Indonesian)]. https://kesmas.kemkes.go.id/assets/upload/ dir_60248a365b4ce1e/ files/RENCANA-AKSI-PROGRAMKESMAS-2015-2019-edit-11-April-2018_1023.pdf

Lawaceng, C. \& Rahayu, A. Y. S., 2019. [The challenges of preventing stunting in Indonesia in the new normal era through community engagement (Indonesian)]. Jurnal Kebijakan Kesehatan Indonesia, 9(3), pp. 136-46. https://journal.ugm.ac.id/jkki/ article/view/57781

Mantovani, S. A. S., et al. 2016. Stunting in children under five years old is still a health problem in the Western Brazilian Amazon: A population-based study in Assis Brasil, Acre, Brazil. Ciencia \& Saude Coletiva, 21(7), pp. 2257-66. [DOI:10.1590/141381232015217.18602014] [PMID]

Marni, L., 2020. [Impact of environmental sanitation quality on stunting (Indonesian)]. Jurnal Stamina, 3(12), pp. 865-72. http:/ / stamina.ppj.unp.ac.id/index.php/JST/article/view/699

de Menezes, R. C. E., et al. 2011. Determinants of stunting in children under five in Pernambuco, Northeastern Brazil. Revista de Saude Publica, 45(6), pp. 1079-87. [DOI:10.1590/S003489102011000600010] [PMID]

Murti, F. C., Suryati, S. \& Oktavianto, E., 2020. [Relationship between Low Birth Weight (LBW) and stunting incidence in toddlers age 2-5 years in Umbulrejo village, Ponjong district, Gunung Kidul Regency (Indonesian)]. Jurnal Keperawatan dan Kesehatan, 16(2), pp. 52-60. [DOI:10.26753/jikk.v16i2.419]

Ni'mah, C. \& Muniroh, L., 2015. [Relationship between education level, knowledge level and mother's parenting pattern with wasting and stunting in under-five poor families (Indonesian)]. Media Gizi Indonesia, 10(1), pp. 84-90. https://e-journal.unair. ac.id/MGI/article/view/3131

Rahayu, A. \& Khairiyati, L., 2014. [Risk of mother's education on stunting incidence in children 6-23 months (Indonesian)]. The Journal of Nutrition and Food Research, 37(2), pp. 129-36. http:// ejournal.litbang.depkes.go.id/index.php/pgm/

Rangki, L., et al. 2020. Risk factors of stunting in children age 24-59 months old. Media Keperawatan Indonesia, 3(1), pp. 10-6. [DOI:10.26714/mki.3.1.2020.10-16]

van Stuijvenberg, M. E., et al. 2015. Low intake of calcium and vitamin $\mathrm{D}$, but not zinc, iron or vitamin $\mathrm{A}$, is associated with stunting in 2-to 5-year-old children. Nutrition, 31(6), pp. 841-6. [DOI:10.1016/j.nut.2014.12.011] [PMID]

Sulastri, D., 2012. [Determinants of stunting in school-age children in Lubuk Kilangan District, Padang City (Indonesian)].
Majalah Kedokteran Andalas, 36(1), pp. 39-50. [DOI:10.22338/ mka.v36.i1.p39-50.2012]

Sutan, R., et al. 2014. Determinant of low birth weight infants: A matched case control study. Open Journal of Preventive Medicine, 4(3), pp. 91-9. [DOI:10.4236/ojpm.2014.43013]

Titaley, C. R., et al. 2019. Determinants of the stunting of children under two years old in Indonesia: A multilevel analysis of the 2013 Indonesia Basic Health Survey. Nutrients, 11(5), p. 1106. [DOI:10.3390/nu11051106] [PMID] [PMCID]

Vilcins, D., Sly, P. D. \& Jagals, P., 2018. Environmental risk factors associated with child stunting: A systematic review of the literature. Annals of Global Health, 84(4), p. 551-62. [DOI:10.29024/aogh.2361] [PMID] [PMCID]

Walker, S. P., et al. 2007. Child development: Risk factors for adverse outcomes in developing countries. The Lancet, 369(9556), pp. 145-57. [DOI:10.1016/S0140-6736(07)60076-2]

Walson, J. L. \& Berkley, J. A., 2018. The impact of malnutrition on childhood infections. Current Opinion in Infectious Diseases, 31(3), p. 231-6. [DOI:10.1097/QCO.0000000000000448] [PMID] [PMCID]

$\mathrm{Wu}$, L., et al. 2015. The relationship between socioeconomic development and malnutrition in children younger than 5 years in China during the period 1990 to 2010. Asia Pacific Journal of Clinical Nutrition, 24(4), pp. 665-73. [DOI:10.6133/ apjen.2015.24.4.24] [PMID]

Zottarelli, L. K., Sunil, T. S. \& Rajaram, S., 2007. Influence of parental and socioeconomic factors on stunting in children under 5 years in Egypt. EMHI-Eastern Mediterranean Health Journal, 13(6), pp. 1330-42. [DOI:10.26719/2007.13.6.1330] [PMID] 
This Page Intentionally Left Blank 